\title{
Effects of the aqueous extract of a Tibetan herb, Rhodiola algida var. tangutica on proliferation and HIF- $1 \alpha$, HIF-2 $\alpha$ expression in MCF-7 cells under hypoxic condition in vitro
}

Yu-juan Qi ${ }^{1,2}$, Sen Cui ${ }^{3}$, Dian-xiang Lu², Ying-zhong Yang ${ }^{2}$, Yushuang Luo ${ }^{2,3}$, Lan Ma², Yan Ma², Tana Wuren²,

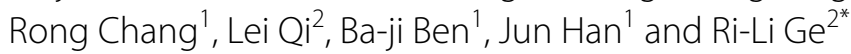

\begin{abstract}
Ethnopharmacological relevance: Rhodiola algida var. tangutica is a traditional Tibetan herb. Its root and rhizome have been successfully used as an effective clinical remedy for the prevention and treatment of cancer and highaltitude sickness. This study aimed to investigate the effect of Rhodiola algida var. tangutica on hypoxic MCF-7 breast cancer cells and the underlying mechanisms.

Materials and methods: The antiproliferative effects of R. algida on MCF-7 breast cancer cells were compared in vitro under hypoxic and normal conditions by using MTT analysis. The influence of R. algida on cancer cell apoptosis was determined by flow cytometry. The expression levels of hypoxia-inducible factor (HIF)-1 $\alpha$ and HIF-2 $\alpha$ were evaluated by western blot analysis.

Results: R. algida inhibited the proliferation of MCF-7 breast cancer cells in a dose- and time-dependent manner. The results of flow cytometry indicated that the antiproliferative effect of $R$. algida was mediated by apoptosis induction. Pretreatment with $R$. algida significantly suppressed the hypoxia-induced proliferation and expression of HIF-1 $\alpha$ and HIF-2 $\alpha$ in MCF-7 breast cancer cells.

Conclusions: R. algida might exert an anti-carcinogenic effect on MCF-7 breast cancer cells by decreasing the protein levels of HIF-1 $\alpha$ and HIF-2 $\alpha$, which are overexpressed under hypoxic conditions. This effect might be elicited by inhibiting the hypoxia-induced proliferation of MCF-7 breast cancer cells.
\end{abstract}

Keywords: Rhodiola algida var. tangutica, MCF-7 breast cancer cell, HIF-1 $\alpha$, HIF-2 $\alpha$, Hypoxic

\section{Background}

Breast cancer is the most common malignancy in women in China [1]. Its annual age-standardized incidence estimates was 21.6 per 100,000 women in 2008. The mortality and incidence rates are substantially higher in urban compared to rural areas (35.6 versus 15.5 per 100,000; 6.90 versus 4.60 per 100,000 in 2008) [2]. Breast cancer also seems more aggressive in China than in developed

\footnotetext{
*Correspondence: geriligao@hotmail.com

${ }^{2}$ Research Center for High Altitude Medicine in Qinghai University, 16

Kunlun Road, Xining 810001, Qinghai, Peoples'Republic of China

Full list of author information is available at the end of the article
}

countries, although tumor size and stage at diagnosis decreases year by year [3]. Among women in economically developed Chinese provinces and cities, breast cancer has the highest incidence of all cancers.

Hypoxia is a common feature of solid tumour, most of the cancer cells grow fast and suffer nutrition and oxygen deficiency under hypoxia [4]. Hypoxia response pathways are complicated and offer many options for anticancer treatment. One of the main and relatively hypoxic response pathways involves hypoxia-inducible factor (HIF)-1, which has therefore been studied as a tumorspecific target for anticancer treatment $[5,6]$. The HIF DNA binding complex is a heterodimer of alpha and beta 
subunits, both of which are basic helix-loop-helix transcription factors. The $\beta$-subunit of HIF is a constitutive nuclear protein, which is critically involved in a range of transcriptional systems, and was first identified in the context of the xenobiotic response. In cells replete with oxygen, HIF- $\alpha$ subunits are unstable, being rapidly destroyed by the ubiquitin-proteasome pathway. When oxygen tension is lowered, HIF- $\alpha$ subunits are stabilised, translocate to the nucleus, and dimerise with a beta subunit. HIF activation is indeed very common in malignant tumours, and have given insights into the underlying mechanisms. And activates transcription of a range of genes via specific enhancer elements termed hypoxia response elements.

Recently, research has been focused on a homologous member of the HIF family. Both factors, HIF-1 and HIF2 , are regulated in similar ways but have different transactivation domains, implying that they may regulate distinct target genes [7,8].

The key regulators of hypoxia-induced angiogenesis are the HIF family of protein transcription factors [9]. HIF regulates multiple factors such as VEGF, and nitric oxide synthases to promote tumor growth and angiogenesis. Hypoxic cells undergo a switch from aerobic to anaerobic glucose metabolism. This adaptive response to hypoxia involves the coordinated expression of many genes regulated by HIF, such as those that encode GLUT1, GLUT3, and various glycolytic enzymes [10].

The genus Rhodiola L. (Crassulaceae) consists of nearly 200 species in which 20 species are commonly used in traditional medical practice in Eastern Europe and Asia [10, 11]. Of these 20 species, Rhodiola algida, Rhodiola rosea, Rhodiola sachalinensis, Rhodiola kirilowii, Rhodiola crenulata, Rhodiola stropupurea, Rhodiola qundrifida, and Rhodiola sera are the most effective ones.

In China, $R$. crenulata $\mathrm{H}$. Ohba is the only authorized herb according to Chinese Pharmacopoeia. However, many other species are also popular in folk medicines such as $R$. algida. Rhodiola algida var. tangutica is a traditional Tibetan herb and grows at an altitude of 3,000$4,500 \mathrm{~m}$ in the Qinghai-Tibetan plateau. The medicinal use of the plant is usually concentrated in the roots and rhizomes that contain its main bioactive compounds [12].

Rhodiola plants are prescribed to increase physical endurance, work productivity, longevity, resistance to high latitude sickness, and to treat fatigue, depression, nervous system disorders, etc. [13]. $R$. algida is one of the most effective species of Rhodiola L. and has been clinically proven to enhance human immune responses $[10,11]$. Despite these findings, the role of $R$. algida as an immunomodulatory agent has been established [14].

Salidroside is regarded as the most important bioactive component and has been used extensively as an indicator for quality evaluation of many Rhodiola species and products
[15]. Salidroside and tyrosol were the main component of Rhodiola algida var. tangutica [16]. Therefore, salidroside was selected in this study as a standard marker to evaluate the quality consistency among different batches of $R$. algida.

The effective components of Rhodiola have been studied extensively during recent years; the extract of Rhodiola algida var. tangutica inhibits division of MCF-7 cells and the cytostatic and antiproliferative effect was related to apoptosis induction mechanism [16]. However, whether it plays an anti-carcinogenic effect under hypoxia condition is yet unclear. The aim of the study is Rhodiola algida var. tangutica inhibits tumor cell proliferation and transcription factor regulation under hypoxia. In this study, we investigated the pharmacological effect of Rhodiola on the proliferation of hypoxic MCF-7 cells. In addition, HIF- $1 \alpha$ and HIF- $2 \alpha$ expression levels in cultured MCF-7 cells exposed to hypoxia were estimated in vitro.

\section{Methods}

\section{Reagents}

MCF-7 breast cancer cells were purchased from Shanghai Institute for Biological Sciences. The effective components of $R$. algida var. tangutica were isolated and analyzed by high-performance liquid chromatography (HPLC) at the Northwest Institute of Plateau Biology, Chinese Academy of Sciences. The antibodies against HIF- $1 \alpha$, HIF- $2 \alpha$, and glyceraldehyde-3-phosphate dehydrogenase (GAPDH) were purchased from Abcam (UK). Annexin V-FITC was purchased from BD Biosciences (San Jose, CA, USA). Fetal bovine serum (FBS) and antibiotics were purchased from Gibco/RBL (Gaithersburg, MD, USA).All other reagents were made in China.

\section{Extract preparation}

The rhizomes of ground plants of Rhodiola algida var. tangutica were grown for 3 years in the experimental field of Yushu (altitude 3,800 m) in Qinghai.

The plant material was dried at $80^{\circ} \mathrm{C}$. Next, $10 \mathrm{~g}$ of the ground dry raw material was mixed with $60 \mathrm{~mL}$ of $96 \%$ ethanol. Extraction was carried out in flasks placed on a rotary shaker at $25^{\circ} \mathrm{C}$ in dark for $12 \mathrm{~h}$. The extract was filtered, and the filtrate was evaporated at $35^{\circ} \mathrm{C}$, at reduced pressure $(20 \mathrm{mbar})$. The dry residue $(0.23 \mathrm{~g})$ was dissolved in $5 \mathrm{~mL}$ dimethyl sulfoxide (DMSO) to a final concentration of $2-4.6 \%$. This solution was diluted with distilled water to obtain the following dilutions: $45,90,180,225$, 360 , and $450 \mu \mathrm{g} / \mathrm{mL}$; the maximal concentration of DMSO in the obtained dilutions did not exceed $0.5 \%$. A solution of $0.5 \%$ DMSO was used as a control in all our experiments.

\section{HPLC analysis}

HPLC analysis was performed using a Phenomenex Kromasil C18 column $(5 \mathrm{~m}, 250 \mathrm{~mm} \times 460 \mathrm{~mm})$, equipped 
with a UVD detector. Separation was performed using an EC $250 / 4$ Nucleosil $^{\circledR} 120-7 C 18$ column (Machery-Nogel). The mobile phase consisted of methanol (A) and $0.01 \mathrm{M}$ $\mathrm{H}_{3} \mathrm{PO}_{4}(\mathrm{~B})$, used in the following gradient elution: from $5 \%$ A for $0 \mathrm{~min}$ to $5 \%$ A for $10 \mathrm{~min}$ to $100 \%$ A for $60 \mathrm{~min}$. The flow rate was $1 \mathrm{~mL} / \mathrm{min}$, and the detection wavelength was $220 \mathrm{~nm}$. The results of our investigations determined that the main component of Rhodiola algida Var. tangutica contained salidroside and tyrosol [16]. The standard substances, i.e., salidroside [15], tyrosol, and other fractions were analyzed in the same manner. The standard substances purchased from China's food and drug verification research institute (110818-201206). Peaks were assigned by spiking the samples with standard substances and comparing the retention times and UV spectra.

\section{Cell culture}

Cells were cultured in RPMI 1640 containing 10\% (v/v) fetal bovine serum (FBS, Gibco) with $100 \mathrm{U} / \mathrm{mL}$ penicillin and $100 \mathrm{U} / \mathrm{mL}$ streptomycin at $37^{\circ} \mathrm{C}$. The fourth to sixth generation cells were used for the subsequent experiments. Cells were exposed to normoxia $\left(74 \% \mathrm{~N}_{2}, 5 \% \mathrm{CO}_{2}\right.$, and $\left.21 \% \mathrm{O}_{2}\right)$ and hypoxia $\left(93 \% \mathrm{~N}_{2}, 5 \% \mathrm{CO}_{2}\right.$, and $\left.2 \% \mathrm{O}_{2}\right)$.

\section{Morphological changes}

The cells were visually and microscopically inspected each time they were handled. Signs of deterioration of cells included granularity around the nucleus, detachment of the cells from the substrate, and cytoplasmic vacuolation.

\section{Viability studies}

MCF-7 cells were incubated in a metabolic water bath for $72 \mathrm{~h}$ under normoxic condition. Control tubes contained only cells and incubation medium with DMSO and experimental tubes contained cells in medium along with different concentrations of $R$. algida extract (45, 90, $180,225,360$, and $450 \mu \mathrm{g} / \mathrm{mL}$ ). One tube from each of the 6 experimental sets was withdrawn at $0,6,12,24,48$, and $72 \mathrm{~h}$ after incubation and immediately assessed for viability by the trypan blue exclusion method.

\section{Proliferation assays}

The proliferation of MCF-7 breast cancer cells was measured using 3-(4, 5-dimethylthiazal-2-yl)-2, 5-diphenyltetra-zoliumbromide (MTT) assay by colorimetrically measuring the formation of formazan dye. Briefly, MCF-7 breast cancer cells were seeded at a density of 10,000 cells/ $\mathrm{cm}^{2}$ in 96-well plates. The cells were incubated for $24 \mathrm{~h}$ in serum-free RPMI1640 and then exposed to R. algida extract $(0,45,90,180,225,360$, and $450 \mu \mathrm{g} / \mathrm{mL})$ for $48 \mathrm{~h}$ under normoxia or hypoxia condition, namely, N48 h or H48 h group, respectively. Plain RPMI1640 was used as the negative control. At the end of treatment, MTT $(0.25 \mathrm{mg} /$
$\mathrm{mL}$, Sigma, USA) was added to the plates, and incubation was continued for another $4 \mathrm{~h}$ at $37^{\circ} \mathrm{C}$. The supernatant was then carefully removed, and $150 \mu \mathrm{L}$ of DMSO was added to dissolve the formazan crystals. The absorbance of the solubilized product was read at $490 \mathrm{~nm}$ (A490) by using an ELISA reader (Bio-Rad, USA). All determinations were replicated at least three times.

The effects of hypoxia on MCF-7 cells were investigated by measuring cell proliferation by direct cell counting. Cells were seeded at a density of $10,000 \mathrm{cells} / \mathrm{cm}^{2}$ in 12-well plates and incubated in serum-free RPMI1640 for $24 \mathrm{~h}$. They were then stimulated with $R$. algida extract at $0,45,90,180,225,360$, and $450 \mu \mathrm{g} / \mathrm{mL}$. After $48 \mathrm{~h}$, they were washed with phosphate buffered solution, harvested by mild trypsinization, and counted using a hematocytometer. The experiments were conducted under both hypoxic and normoxia conditions.

\section{Flow cytometry}

The mode of cell death via apoptosis and or necrosis produced by the extract treatment in MCF-7 cells was determined by flow cytometry after staining the cells with Annexin V-FITC and PI. Cells were stimulated with R. algida extract at $0,45,90,180,225,360$, and $450 \mu \mathrm{g} /$ $\mathrm{mL}$ for $48 \mathrm{~h}$ under normoxia or hypoxia. Treated cells were washed twice with cold PBS and then resuspended in binding buffer at a concentration of $1 \times 10^{5}$ cells $/ \mathrm{mL}$. Next, $5 \mu \mathrm{L}$ of Annexin V-FITC and $10 \mu \mathrm{L}$ of propidium iodide were added to suspended cells. After incubation for $10 \mathrm{~min}$ at room temperature in the dark, the percentage of apoptotic cells was calculated using a flow cytometer (Becton-Dickinson, USA) equipped with argon laser having an emission spectrum of $488 \mathrm{~nm}$. The percentages of apoptotic and necrotic cells were evaluated.

\section{Determination of HIF- $1 \alpha$ and HIF- $2 \alpha$ expression by western blot analysis}

MCF-7 cells were exposed to normoxia or hypoxia in the absence or presence of $R$. algida extract in the indicated concentrations. Cells were lysed in whole lysis buffer $(0.1 \%$ Nonidet P-40, $5 \mathrm{mM}$ ethylenediaminetetraacetic acid (EDTA), $50 \mathrm{mM}$ Tris (pH 8.0), $250 \mathrm{mM} \mathrm{NaCl}$, and $50 \mathrm{mM}$ $\mathrm{NaF}$ ), and protein concentrations were determined using the Bio-Rad Protein assay (Bradford). Subsequently, $30 \mu \mathrm{g}$ protein was resolved on $10 \%$ sodium dodecyl sulfate-polyacrylamide gel electrophoresis (SDS-PAGE) and transferred to nitrocellulose membranes. The membranes were blocked with $5 \%$ skimmed milk-PBS/0.1\% Tween 20 for $2 \mathrm{~h}$ before an overnight incubation at room temperature with primary antibodies in 5\% skimmed milk in PBS/0.1\% Tween 20 . The corresponding secondary antibody was washed with Tris-buffered saline with Tween20 (TBST) for $30 \mathrm{~min}$ and added to the membranes, followed by incubation at room 
temperature for $2 \mathrm{~h}$. The membranes were then washed three times for $10 \mathrm{~min}$ each with TBST. Detection was performed using the enhanced chemiluminescence system (Amersham, Arlington Heights, IL, USA). The relative expression levels of HIF- $1 \alpha$ and HIF- $2 \alpha$ were normalized against that of GAPDH.

\section{Statistical analysis}

The statistical significance of differences between groups was evaluated by one-way analysis of variance (ANOVA), followed by Dunnett's test for multiple comparisons. A $p$ value of $<0.05$ was considered as statistically significant.

\section{Results}

\section{Effect of hypoxia on MCF-7 cell proliferation}

MCF-7 breast cancer cells were cultured under hypoxic or normoxic condition for $12,24,48$, and $72 \mathrm{~h}$, as described previously. Subsequently, cell proliferation was measured by the MTT assay. The absorbance at $490 \mathrm{~nm}$ was detected. Hypoxia-induced MCF-7 breast cancer cells showed proliferation especially at $48 \mathrm{~h}$ (Table 1 ). Therefore, $48 \mathrm{~h}$ of incubation was used for the subsequent experiments.

Table 1 Effect of hypoxic on proliferation of MCF-7 breast cancer cells (absorbance at $490 \mathrm{~nm}, \mathrm{A490}$ )

\begin{tabular}{lllll}
\hline & $\mathbf{1 2} \mathbf{h}$ & $\mathbf{2 4} \mathbf{h}$ & $\mathbf{4 8} \mathbf{h}$ & $\mathbf{7 2} \mathbf{h}$ \\
\hline Normoxia & $0.272 \pm 0.023$ & $0.289 \pm 0.019$ & $0.315 \pm 0.031$ & $0.331 \pm 0.003$ \\
Hypoxia & $0.298 \pm 0.031$ & $0.319 \pm 0.044^{\mathrm{a}}$ & $0.351 \pm 0.034^{\mathrm{a}}$ & $0.362 \pm 0.044^{\mathrm{a}}$ \\
\hline
\end{tabular}

The data represented mean \pm S.D. $(n=15)$.

a $P<0.05$ vs. normoxia.

\section{In vitro viability studies on cytotoxicity of $R$. algida var. tangutica}

The cytotoxicity of $R$. algida extract on MCF-7 cells was evaluated by the trypan blue dye exclusion method, and the appropriate concentrations of the plant extract to be used was determined. The MCF-7 $\left(2 \times 10^{5}\right.$ cells/well $)$ breast cancer cells were incubated for $24 \mathrm{~h}$ in 96-well plates with various concentrations of $R$. algida extract (0, 45, 90, 180, 225, 360, and $450 \mu \mathrm{g} / \mathrm{mL})$. Dose-dependent cytotoxic effect of the plant extract against MCF-7 breast cancer cells is shown in Fig. 1. The concentration of $450 \mu \mathrm{g} / \mathrm{mL}$ significantly decreased the number of viable cells and produced microscopic changes in morphology compared with those of the controls. Hence, the doses of $360 \mu \mathrm{g} / \mathrm{mL}$ or less were selected for subsequent experiments since these doses had weak cytotoxic effects on MCF-7 cells. However, with increasing incubation times, even low doses of $R$. algida extract significantly decreased cell viability.

\section{Morphology}

Morphological changes in MCF-7 breast cancer cells treated with $R$. algida extract under $2.0 \% \mathrm{O}_{2}$ or normoxic condition were observed microscopically (Fig. 2). The cells showed shrinkage, chromatin compaction, and cytoplasmic vacuolation. Treatment with $R$. algida extract increased the apoptotic cell numbers (Fig. 2). Cell morphology was markedly changed after $48 \mathrm{~h}$ incubation with $360 \mu \mathrm{g} / \mathrm{mL}$ R. algida extract.

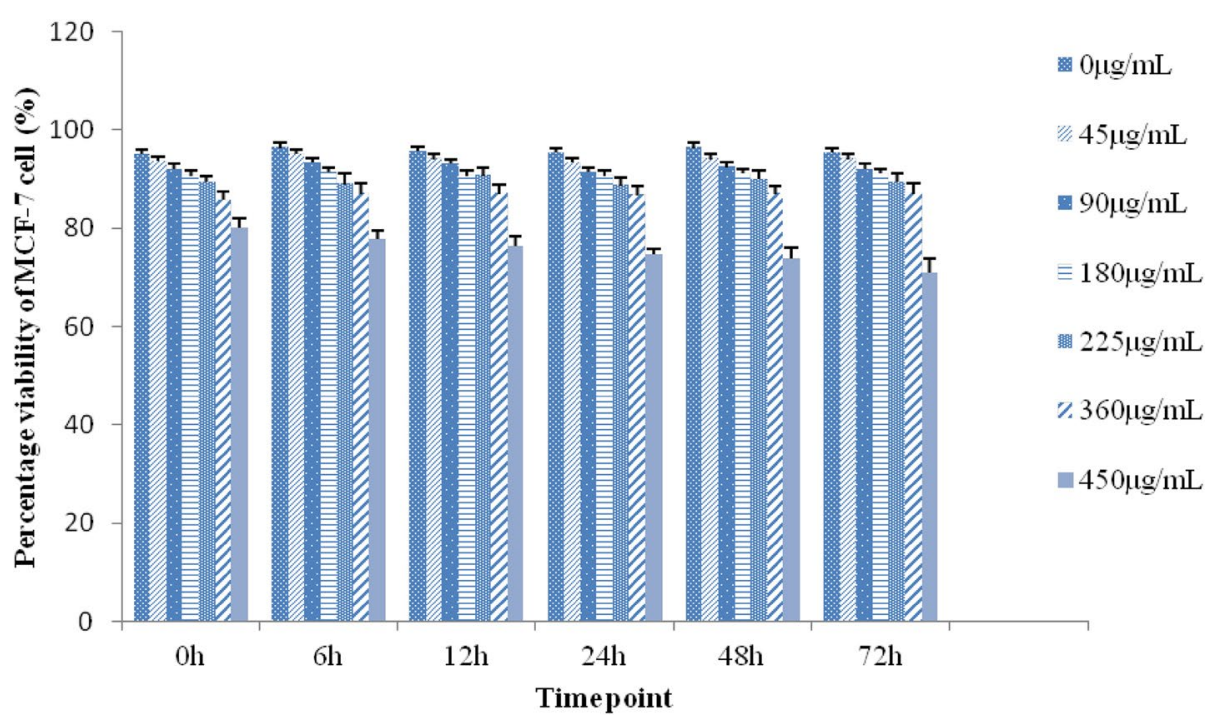

Fig. 1 Effect of Rhodiola algida var. tangutica on the viability of MCF-7 cell. MCF-7 cell were cultured in microwells and incubated with increasing concentrations of Rhodiola algida var. tangutica $0,6,12,24,48$ and $72 \mathrm{~h}$ after incubation with different concentrations of Rhodiola algida var. tangutica, percentage viability of MCF-7 cell was determined by trypan blue exclusion. The highest concentration ( $450 \mu \mathrm{g} / \mathrm{mL})$ of Rhodiola algida var. tangutica caused a significant decrease in cell viability compared with control. 


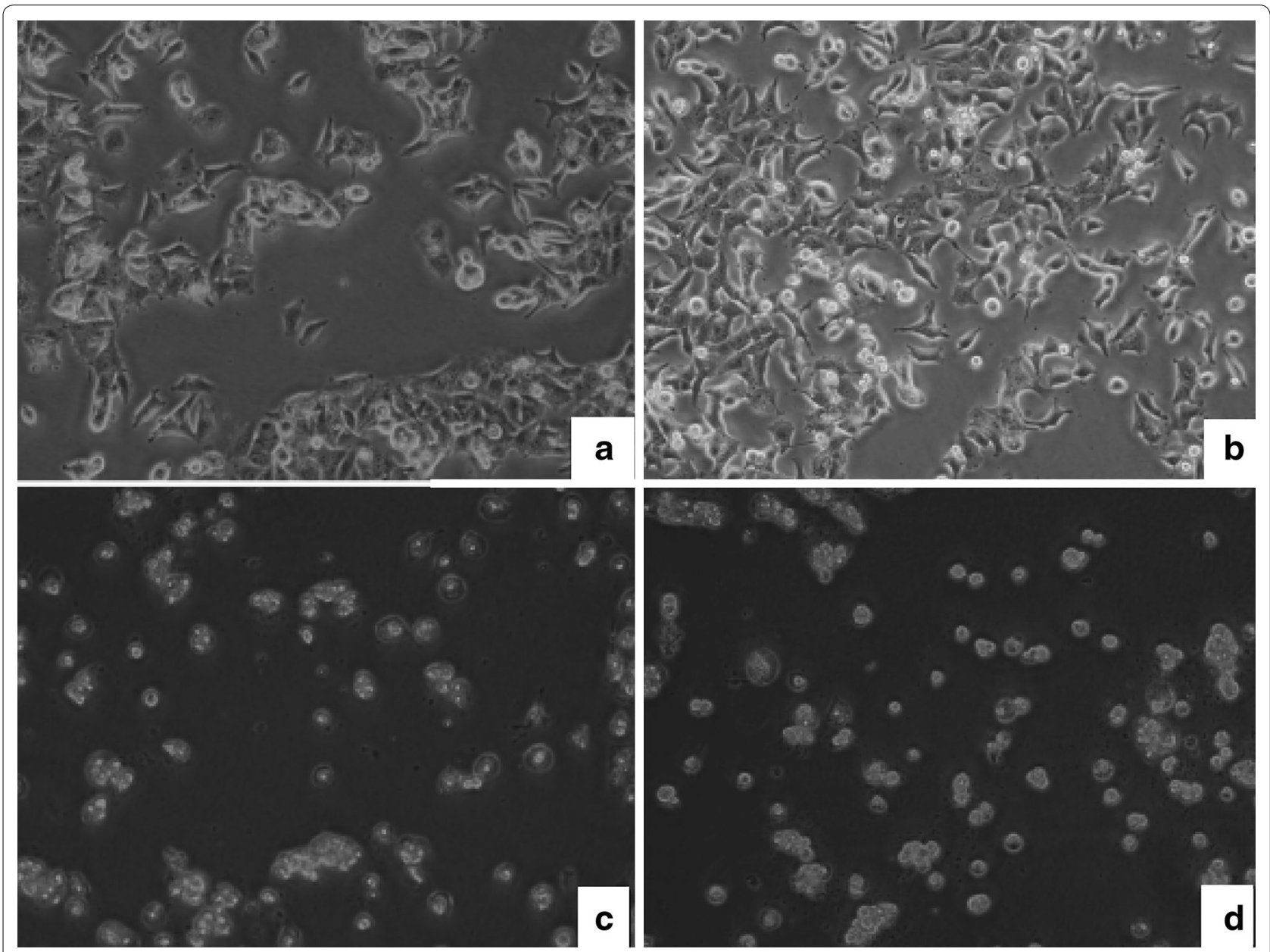

Fig. 2 Rhodiola algida var. tangutica inhibits hypoxia-induced proliferation in MCF-7 cells. The cells were plated at a seeding density of $5 \times 10^{4}$ viable cells $/ \mathrm{cm}^{2}$ and grown as a monolayer in a $37^{\circ} \mathrm{C}$ incubator with a humidified atmosphere of $5 \% \mathrm{CO}_{2}$ in a $2.0 \%$ O $\mathrm{O}_{2}$ or normoxic. The images were obtained using 20x objectives $48 \mathrm{~h}$ after plating. a Morphology from normal MCF-7 breast cancer cells in adherent culture exposed to normoxic $48 \mathrm{~h}$ (N48h). b Morphology from MCF-7 breast cancer cells in adherent culture exposed to hypoxia $48 \mathrm{~h}$ (H48h), showing proliferation after exposure to hypoxia. c Morphology from MCF-7 breast cancer cells in adherent culture receiving Rhodiola algida var. tangutica (360 $\mu \mathrm{g} / \mathrm{mL}) \mathrm{for} 48 \mathrm{~h}$ under normoxic condition (N48h + Rhodiola algida var. tangutica group), showing shrinkage and chromatin compaction in normal MCF-7 breast cancer cells. d Morphology from MCF-7 breast cancer cells in adherent culture receiving Rhodiola algida var. tangutica $(360 \mu \mathrm{g} / \mathrm{mL})$ after exposure to hypoxia for $48 \mathrm{~h}$ ( $\mathrm{H} 48 \mathrm{~h}+$ Rhodiola algida var. tangutica group).

\section{Identification of apoptosis by flow cytometry analysis}

The percentage of MCF-7 cells increased under the hypoxic condition, but this increase in cell proliferation was markedly decreased by treatment with $R$. algida extract (Fig. 3). The data represented mean \pm S.D. ( $\mathrm{n}=15) . \mathrm{P}<0.05$ vs. normoxia. This suggested that $R$. algida var. tangutica induced apoptosis under hypoxia in MCF-7 breast cancer cells.

\section{Effects of $R$. algida extract on MCF-7 breast cancer cell proliferation under normoxic and hypoxic conditions}

Evaluation of whether $R$. algida extract affected the proliferation of MCF-7 cells induced by hypoxia was performed using the MTT assay and direct cell counting for nonradioactive quantification of cell proliferation. The results showed that $R$. algida extract inhibited the hypoxia-induced proliferation of MCF-7 cells in a concentration-dependent manner. Significantly reduced cell proliferation of treated cells was also noted under normoxic condition, although at lower concentrations of R. algida extract (180 and $225 \mu \mathrm{g} / \mathrm{mL}$; Table 2 ). Similar results were obtained by direct cell counting (Fig. 4).

\section{Effect of $R$. algida extract on HIF- $1 \alpha$ and HIF- $2 \alpha$ protein expression in cultured MCF-7 breast cancer cells}

Hypoxia increased the expressionof HIF- $1 \alpha$ and HIF- $2 \alpha$ in MCF-7 breast cancer cells, whereas treatment with $R$. algida extract (225 and $360 \mu \mathrm{g} / \mathrm{mL}$ ) possibly decreased 


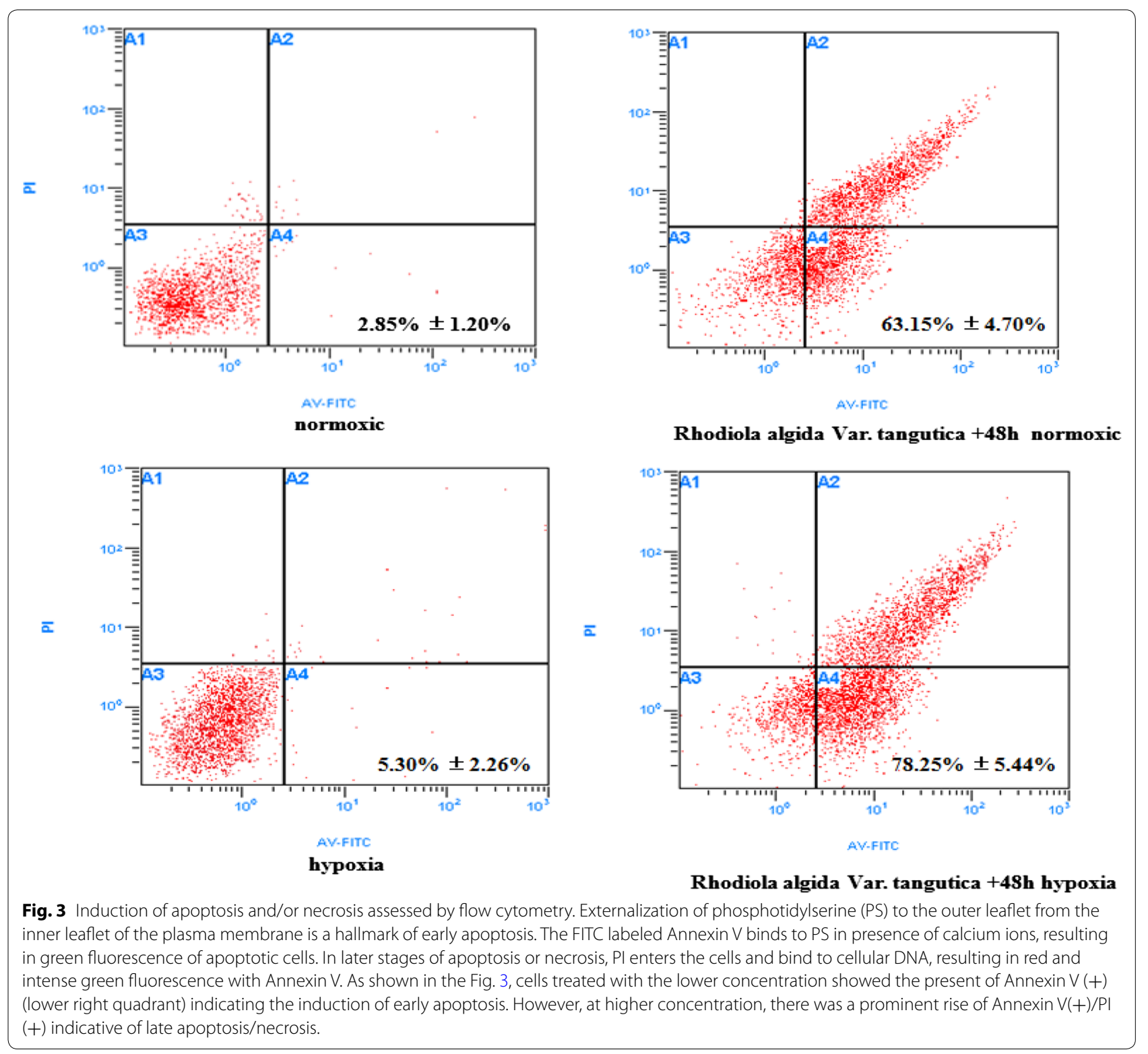

HIF- $1 \alpha$ and HIF- $2 \alpha$ protein expression in cells exposed to hypoxia for $48 \mathrm{~h}$ (Fig. 5, a-c).

\section{Discussion}

Breast cancer has an incidence rate of 16.39 per 100,000 Chinese women and seriously affects the lives and health of this population. Gene targeting involving substances that target hypoxic cells might be an excellent strategy. The transcriptional factor HIF-1 plays an essential role in the adaptive response of cells to reduced oxygen tension [17]. The induction of HIF-1 $\alpha$ is a critical step in the induction of hypoxic response and occurs via increased mRNA expression, protein stabilization, and nuclear localization. Additional isoforms of the $\alpha$-subunit termed
HIF- $2 \alpha$ and HIF- $3 \alpha$ are present. HIF- $2 \alpha$ is closely related to HIF- $1 \alpha$, and both subunits can interact with hypoxiaresponse elements to upregulate their transcriptional activity [18]. In contrast, HIF-3 $\alpha$ is involved in the downregulation of the hypoxic response via the activation of an alternatively spliced transcription factor, which may function as an inhibitor of HIF-1 $\alpha$ [19]. An efficient gene delivery system needs to be developed to increase the efficiency and reduce toxicity of Rhodiola spp. The property of Rhodiola spp. to suppress the proliferation of cancer cells under hypoxic condition can be used to induce therapeutic gene expression specifically in the tumor tissue.

Extract of $R$. algida has been known to exert many beneficial effects in the treatment of numerous diseases, 
Table 2 Effect of Rhodiola algida Var. tangutica on proliferation of MCF-7 breast cancer cells exposed to normoxia and hypoxia for $48 \mathrm{~h}$ (absorbance at $490 \mathrm{~nm}, \mathrm{A490}$ )

\begin{tabular}{llllllll}
\hline Rhodiola algida var. tangutica & $\mathbf{0} \boldsymbol{\mu} \mathbf{g} / \mathbf{m L}$ & $\mathbf{4 5} \boldsymbol{\mu \mathbf { g } / \mathbf { m L }}$ & $\mathbf{9 0} \boldsymbol{\mu \mathbf { g } / \mathbf { m L }}$ & $\mathbf{1 8 0} \boldsymbol{\mu \mathbf { g } / \mathbf { m L }}$ & $\mathbf{2 2 5} \boldsymbol{\mu \mathbf { g } / \mathbf { m L }}$ & $\mathbf{3 6 0} \boldsymbol{\mu \mathbf { g } / \mathbf { m L }}$ & $\mathbf{4 5 0} \boldsymbol{\mu \mathbf { g } / \mathbf { m L }}$ \\
\hline $\mathrm{N} 48 \mathrm{~h}$ & $0.301 \pm 0.070$ & $0.296 \pm 0.059$ & $0.284 \pm 0.067$ & $0.273 \pm 0.058$ & $0.265 \pm 0.043$ & $0.247 \pm 0.045^{\mathrm{a}}$ & $0.239 \pm 0.062^{\mathrm{a}}$ \\
$\mathrm{H} 48 \mathrm{~h}$ & $0.358 \pm 0.048$ & $0.346 \pm 0.054$ & $0.327 \pm 0.078$ & $0.314 \pm 0.057$ & $0.308 \pm 0.071^{\mathrm{b}}$ & $0.274 \pm 0.067^{\mathrm{b}}$ & $0.266 \pm 0.074^{\mathrm{b}}$
\end{tabular}

The data represented mean \pm S.D. $(n=9)$. $N 48 \mathrm{~h}$ indicates exposure to normoxia for $48 \mathrm{~h}$; $\mathrm{H} 48 \mathrm{~h}$, exposure to hypoxia for $48 \mathrm{~h}$.

a $\mathrm{P}<0.05$ vs. $\mathrm{N} 48 \mathrm{~h}$ in the absence of Rhodiola algida var. tangutica.

b $\mathrm{P}<0.05$ vs. $\mathrm{H} 48 \mathrm{~h}$ in the absence of Rhodiola algida var. tangutica.

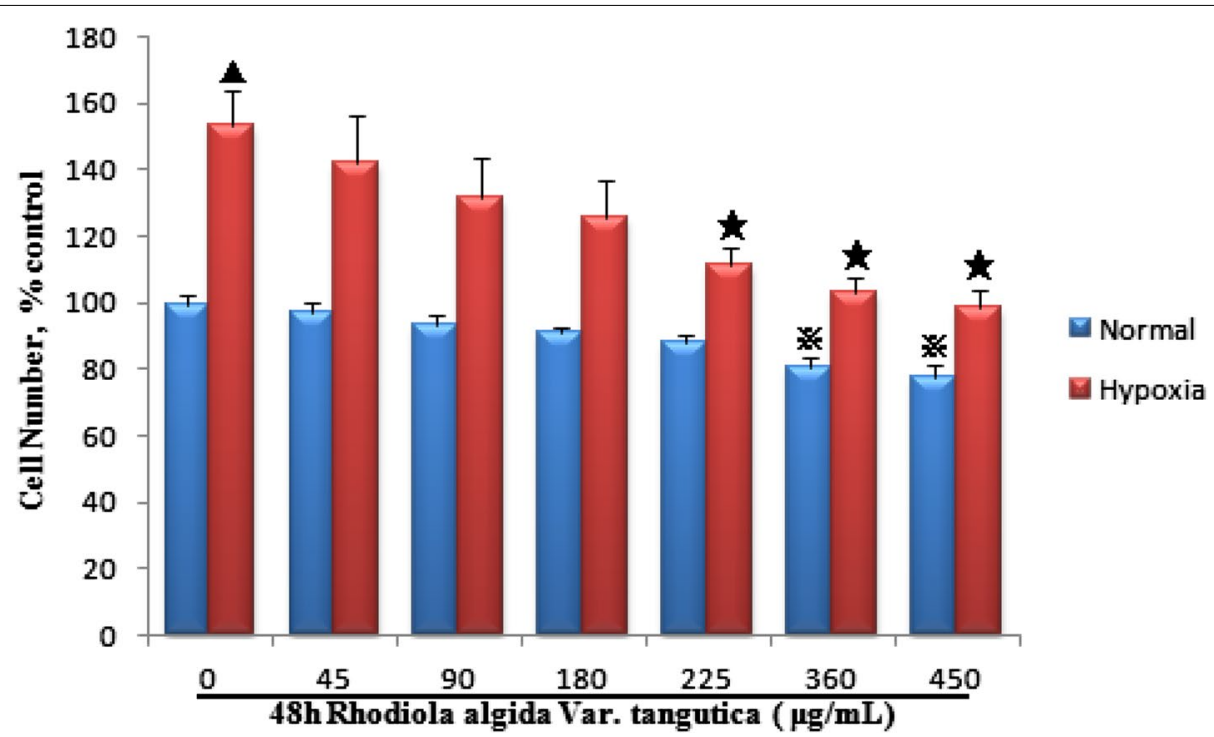

Fig. 4 Effect of Rhodiola algida var. tangutica on proliferation of MCF-7 breast cancer cells exposed to normoxia and hypoxia for $48 \mathrm{~h}$ by direct cell counting. Serum-starved MCF-7 breast cancer cells exposed to normoxia and hypoxia were incubated with Rhodiola algida var. tangutica at different concentrations $(0,45,90,180,225,360 \mu \mathrm{g} / \mathrm{mL})$ for $48 \mathrm{~h}$. And then the cell counts were determined with a hematocytometer. Values are expressed as percentage of untreated cells, and each bar represents the mean \pm S.D. of triplicate determinations. N48 $\mathrm{h}$ indicates exposure to normoxia for 48 h; H48 h, exposure to hypoxia for 48 h. ${ }^{*} \mathrm{P}<0.05$ vs. N48 h in the absence of Rhodiola algida var. tangutica. $\boldsymbol{\Delta}_{\mathrm{P}}<0.01$ vs. N48 h in the absence of Rhodiola algida var. tangutica; ${ }^{\star} \mathrm{P}<0.05 \mathrm{vs}$. $\mathrm{H} 48 \mathrm{~h}$ in the absence of Rhodiola algida var. tangutica.

probably via different mechanisms reported. For example, salidroside protects endothelial cells from cobalt chloride-induced apoptosis by acting as an antioxidant and regulating the expression of Bcl-2 family members [20]. The protective effect of salidroside has been shown to be closely associated with the activation of the transcription factor HIF-1 $\alpha$ along with its target gene VEGF [21]. Previous studies have shown that treatment of human peripheral blood mononuclear cells (PBMCs) with Rhodiola aqueous extract (RAE) increased the levels of interleukin (IL)- 6 and tumor necrosis factor- $\alpha$ (TNF$\alpha$ ) via the phosphorylation of IкB and transcription factor NF- $k B$; this suggests that RAE has immunostimulatory potential [22]. In some previous study, we found that $R$. rosea aqueous extract, hydroalcoholic extract, and rosavin induced anti-angiogenic activity in the tumorinduced angiogenesis model [23]. Oral administration of $R$. rosea extract to patients with superficial bladder carcinoma led to the improvement in the characteristics of the urothelial tissue integration and $\mathrm{T}$ cell immunity [24]. Salidroside induces cell-cycle arrest and apoptosis in human breast cancer cells and may be a promising candidate for breast cancer treatment [25].

The $R$. rosea extract and salidroside inhibit translation initiation. Both the $R$. rosea extract and salidroside treatment of UMUC3 bladder cells caused a significant percentage of cells undergoing autophagy. The $R$. rosea extract and salidroside deserve further study as novel agents for chemoprevention of bladder carcinogenesis [26]. The inhibitory effects of salidroside on tumor metastasis in human fibrosarcoma HT1080 cells in vitro. Salidroside inhibits tumor cells metastasis, which may due to its interfere in the intracellular excess ROS thereby down-regulated the ROS-PKC-ERK1/2 signaling pathway [27]. Angiogenesis was induced in the skin of Balb/c mice by grafting of syngeneic L-1 sarcoma cells. Mice were 


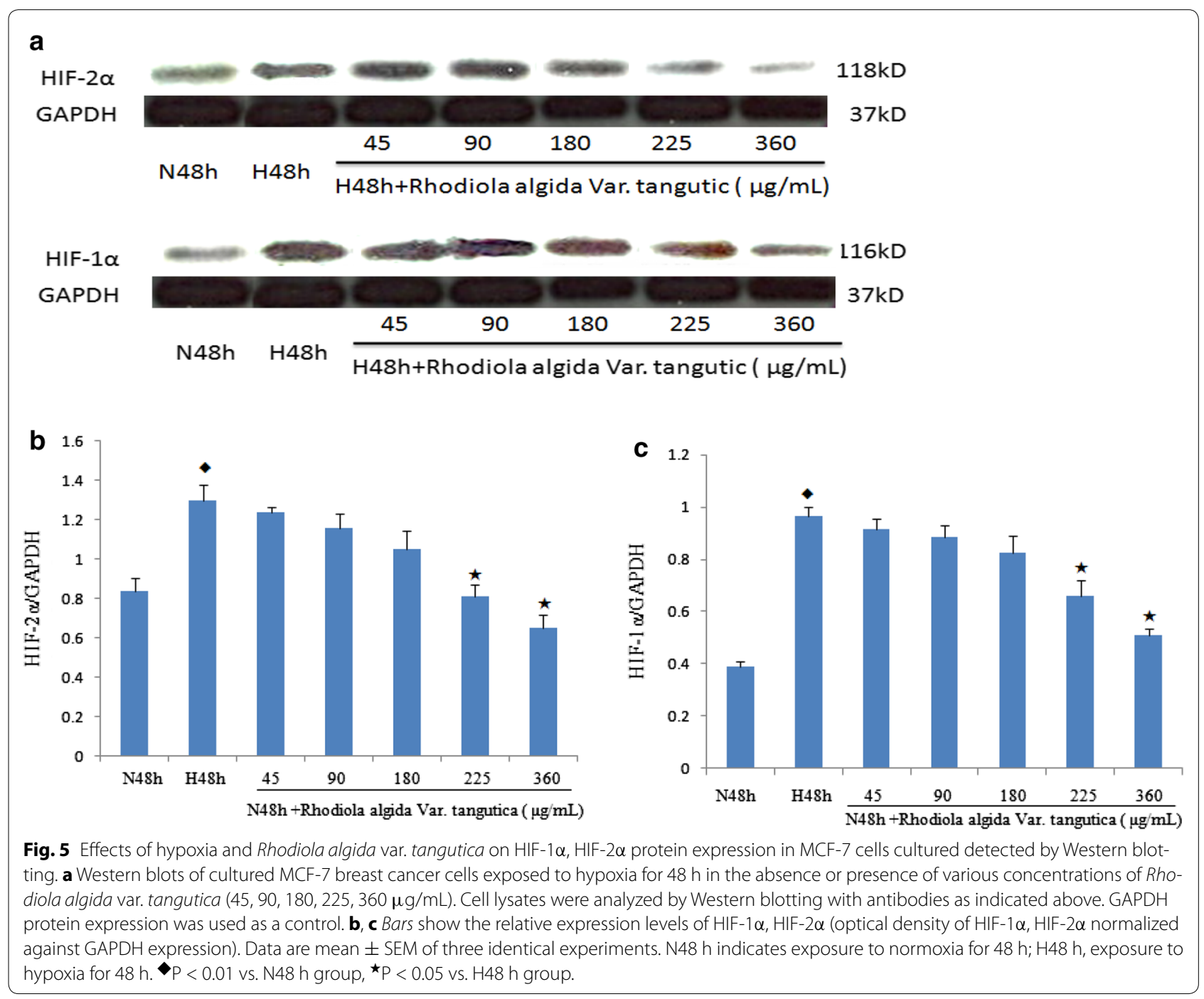

fed $R$. quadrifida extract or salidroside in daily different doses. After 72 h, R. quadrifida extract and salidroside significantly decreased neovascular reaction in all doses applied [23].

In the present study, cultured MCF-7 breast cancer cells exposed to $R$. algida extract at concentrations of $45-360 \mu \mathrm{g} / \mathrm{mL}$ for $48 \mathrm{~h}$ showed no signs of toxicity. The effects of hypoxia on the proliferation of MCF-7 breast cancer cells and expression of HIF subunits was also studied. Majewska reported that the rhizome extract of $R$. rosea inhibits cell division, induces apoptosis and necrosis, and elicits cytostatic and anti-proliferative effects in HL-60 cells [28]. Our results are in agreement with previously reported findings and suggest that $R$. algida var. tangutica prevents the hypoxia-induced proliferation of MCF-7 cells and down-regulates the expression of HIF- $1 \alpha$ and HIF- $2 \alpha$.

\section{Conclusion}

In our research,We found that the proliferation of MCF-7 breast cancer cells increased significantly under hypoxia compared with that of the controls. Our results showed that pretreatment of MCF-7 breast cancer with $R$. algida extract increased cell apoptosis. Moreover, morphological and FACS analyses clearly showed that MCF7 cell proliferation was significantly inhibited by pretreatment with $R$. algida extract under hypoxia. In addition, protein expression of HIF- $1 \alpha$ and HIF- $2 \alpha$ in MCF-7 cells was inhibited by pretreatment with $R$. algida extract. $R$. algida extract maybe as a potential anti-tumor medicane in the future. Although our experiments were performed in vitro, the results provide a basis for using $R$. algida var. tangutica in the treatment of hypoxic breast cancer.

We want to detect the effect of $R$. algida var. tangutica on tumor in vivo in our future research job. 


\section{Abbreviations}

HIF: hypoxia-inducible factor; VEGF: vascular endothelial growth factor; bFGF: basic fibroblast growth factor; GAPDH: glyceraldehyde-3-phosphate dehydrogenase; DMSO: dimethyl sulphoxide; EDTA: ethylenediaminetetraacetic acid; SDS-PAGE: sodium dodecyl sulfate-polyacrylamide gel electrophoresis; ANOVA: analysis of variance; IL: interleukin; TNF- $\alpha$ : tumor necrosis factor- $\alpha$.

\section{Authors' contributions}

R-LG participated in the intellectual design of the study, YQ carried out the culture of MCF-7 breast cancer cell lines, treated the cells with R. algida extract under hypoxic and normal conditions, he viability experiments gene expression and Western blot, and drafted the manuscript. SC participated in the intellectual design of the study. DL and YY participated in the intellectual design of the study, critically revised the manuscript and gave the final approval for submission. All authors read and approved the final manuscript.

\section{Author details}

1 Qinghai Province people's Hospital, Xining 810007, Qinghai, Peoples' Republic of China. ${ }^{2}$ Research Center for High Altitude Medicine in Qinghai University, 16 Kunlun Road, Xining 810001, Qinghai, Peoples'Republic of China. ${ }^{3}$ Qinghai University Affiliated Hospital, Xining 810001, Qinghai, Peoples'Republic of China.

\section{Acknowledgments}

This work was supported by "National Basic Research Program of China No.31160219"; Program of International S\&T Cooperation of China, No. 2011DFA32720; National Program on Key Basic Research Project of China (No.2012CB518200).

Received: 20 May 2014 Accepted: 11 July 2015

Published online: 15 August 2015

\section{References}

1. Ferlay J, Shin HR, Bray F, Forman D, Mathers C, Parkin DM et al (2010) GLOBOCAN 2008 v2.0, Cancer Incidence and Mortality Worldwide: IARC CancerBase No. 10 [Internet], Lyon, France: International Agency for Research on Cancer; 2010. Available from: http://globocan.iarc.fr. Accessed 25 Feb 2013

2. Chen WQ, Zheng RS, Zeng HM, Zhang SW, Li GL, Wu LY et al. (2013) Incidence and mortality of breast cancer in China, 2008. Thoracic Cancer 4:59-65

3. Zheng S, Bai JQ, Li J, Fan JH, Pang Y, Song QK et al. (2012) The pathologic characteristics of breast cancer in China and its shift during 1999-2008: a national-wide multicenter cross-sectional image over 10 years. Int J Cancer 131:2622-2631

4. Yee Koh M, Spivak-Kroizman TR, Powis G (2008) HIF-1 regulation: not so easy come, easy go. Trends Biochem Sci 33(11):526-534

5. Semenza GL (2003) Targeting HIF-1 for cancer therapy. Nat Rev Cancer 3:721-732

6. Wouters BG, Weppler SA, Koritzinsky M, Landuyt W, Nuyts S, Theys J et al (2002) Hypoxia as a target for combined modality treatments. Eur J Cancer 38:240-257

7. Hu CJ, Wang LY, Chodosh LA, Keith B, Simon MC (2003) Differential roles of hypoxia-inducible factor $1 \alpha$ (HIF-1 $\alpha$ ) and HIF-2 $\alpha$ in hypoxic gene regulation. Mol Cell Biol 23:9361-9374

8. Koukourakis MI, Bentzen SM, Giatromanolaki A, Wilson GD, Daley FM, Saunders Ml et al (2006) Endogenous markers of two separate hypoxia response pathways (hypoxia inducible factor 2 alpha and carbonic anhydrase 9) are associated with radiotherapy failure in head and neck cancer patients recruited in the CHART randomized trial. J Clin Oncol 24:727-735

9. Hickey MM, Simon MC (2006) Regulation of angiogenesis by hypoxia and hypoxia-inducible factors. Curr Top Dev Biol 76:217-257

10. Germano C, Ramazanov Z, Bernal Suarez M (1999) Arctic root (Rhodiola rosea): the powerful new ginseng alternative. Kensington Publishing Corporation, New York

11. Kelly GS (2001) Rhodiola rosea: a possible plant adaptogen. Altern Med Rev 6:293-302

12. Wang JX, Luo DQ, Zhao XY (2006) Studies on the chemical constituents of Rhodiola dumulosa (II). Zhong Yao Cai 29:335-336
13. Arora R, Chawla R, Sagar R, Prasad J, Singh S, Kumar R et al (2005) Evaluation of radioprotective activities Rhodiola imbricate Edgew-ahigh altitude plant. Mol Cell Biochem 273:209-223

14. Li HX, Sze SCW, Tong Y, Ng TB (2009) Production of Th1- and Th2-dependent cytokines induced by the Chinese medicine herb, Rhodiola algida, on human peripheral blood monocytes. J Ethnopharmacol 123:257-266

15. Cui S, Hu X, Chen X, Hu Z (2003) Determination of p-tyrosol and salidroside in three samples of Rhodiola crenulata and one of Rhodiola kirilowii by capillary zone electrophoresis. Anal Bioanal Chem 377:370-374

16. Lu DX, Zhang SN, Wang WP, Zhen J (2011) The Study of Cytostatic Effect on MCF-7 Cells of the Alcohol Extract of Rhodiola Algida Var. Tangutica. In: 2011 3rd International Conference on Bioinformatics and Biomedical Technology (ICBBT 2011), pp 228-230

17. Jiang BH, Semenza GL, Bauer C, Marti HH (1996) Hypoxia-inducible factor 1 levels vary exponentially over a physiologically relevant range of $\mathrm{O}_{2}$ tension. Am J Physiol 271 C:1172-1180

18. Semenza GL (1999) Regulation of mammalian $\mathrm{O}_{2}$ homeostasis by hypoxia-inducible factor1. Annu Rev Cell Dev Biol 15:551-578

19. Makino Y, Kanopka A, Wilson WJ, Tanaka H, Poellinger L (2002) Inhibitory PAS domain protein (IPAS) is a hypoxia-inducible splicing variant of the hypoxia-inducible factor-3 $\alpha$ locus. J Biol Chem 277:32405-32408

20. Tan CB, Gao M, Xu WR, Yang XY, Zhu XM, Du GH (2009) Protective effects of salidroside on endothelial cell apoptosis induced by cobalt chloride. Biol Pharm Bull 32:1359-1363

21. Zhang J, Liu A, Hou R, Zhang J, Jia X, Jiang W et al (2009) Salidroside protects cardiomyocyte against hypoxia-induced death: A HIF- $1 \alpha$-activated and VEGF-mediated pathway. Eur J Pharmacol 607:6-14

22. Mishra KP, Padwad YS, Jain M, Karan D, Ganju L, Sawhney RC (2006) Aqueous extract of Rhodiola imbricata rhizome stimulates proinflammatory mediators via phosphorylated IkB, and transcription factor nuclear factorkB. Immunopharmacol Immunotoxicol 28:201-212

23. Skopińska-Rózewska E, Malinowski M, Wasiutyński A, Sommer E, Furmanowa M, Mazurkiewicz M et al (2008) The influence of Rhodiola quadrifida $50 \%$ hydro-alcoholic extract and salidroside on tumor-induced angiogenesis in mice. Pol J Vet Sci. 11(2):97-104

24. Bocharova OA, Matveev BP, Aiu B, Figurin KM, Serebriakova RV, Bodrova NB (1995) The effect of a Rhodiola rosea extract on the incidence of recurrences of a superficial bladder cancer (experimental clinical research). Urol Nefrol (Mosk) 2:46-47

25. Hu X, Zhang X, Qiu S, Yu D, Lin S (2010) Salidroside induces cell-cycle arrest and apoptosis in human breast cancer cells. Biochem Biophys Res Commun 398:62-67

26. Liu Z, Li X, Simoneau AR, Jafari M, Zi X (2012) Rhodiola rosea extracts and salidroside decrease the growth of bladder cancer cell lines via inhibition of the mTOR pathway and induction of autophagy. Mol Carcinog 51:257-267

27. Sun C, Wang Z, Zheng Q, Zhang H (2012) Salidroside inhibits migration and invasion of human fibrosarcoma HT1080 cells. Phytomedicine 19:355-363

28. Majewska A, Hoser G, Furmanowa M, Urbańska N, Pietrosiuk A, Zobel A et al (2006) Antiproliferative and antimitotic effect, S phase accumulation and induction of apoptosis and necrosis after treatment of extract from Rhodiola rosea rhizomes on HL-60 cells. J Ethnopharmacol 103:43-52

\section{Submit your next manuscript to BioMed Central and take full advantage of:}

- Convenient online submission

- Thorough peer review

- No space constraints or color figure charges

- Immediate publication on acceptance

- Inclusion in PubMed, CAS, Scopus and Google Scholar

- Research which is freely available for redistribution

Submit your manuscript at www.biomedcentral.com/submit

C) BioMed Central 